\title{
Changes in species composition during annual cyanobacterial dominance in a tropical reservoir: physical factors, nutrients and grazing effects
}

\author{
Maria Carolina S. Soares ${ }^{1,5, *}$, Maria Isabel de A. Rocha ${ }^{2}$, Marcelo M. Marinho ${ }^{3}$, \\ Sandra M. F. O. Azevedo ${ }^{2}$, Christina W. C. Branco ${ }^{4}$, Vera L. M. Huszar ${ }^{1}$ \\ ${ }^{1}$ Departamento de Botânica, Laboratório Ficologia, Museu Nacional, Universidade Federal do Rio de Janeiro, \\ 20940-040 Rio de Janeiro, Brasil \\ ${ }^{2}$ Laboratório de Ecofisiologia e Toxicologia de Cianobactérias, IBCCF ${ }^{\circ}$, Universidade Federal do Rio de Janeiro, CCS Bl.G, \\ 21949-900 Rio de Janeiro, Brasil \\ ${ }^{3}$ Departamento de Biologia Vegetal, Laboratório de Taxonomia e Ecologia de Algas, Universidade do Estado do Rio de \\ Janeiro, R. São Francisco Xavier N 524, PHLC, 20550-900 Rio de Janeiro, Brasil \\ ${ }^{4}$ Departamento de Ciências Naturais, Universidade Federal do Estado do Rio de Janeiro, Avenida Pasteur 458, \\ 22290-240 Rio de Janeiro, Brasil
}

${ }^{5}$ Present address: Departamento de Biologia, Laboratório de Ecologia Aquática, Universidade Federal de Juiz de Fora, 36036-900 Juiz de Fora, Brasil

\begin{abstract}
Trends in recent years have indicated that cyanobacterial blooms in tropical reservoirs are increasing in frequency, magnitude and geographical distribution. Funil Reservoir in southeastern Brazil has experienced eutrophication in the recent decades, resulting in lasting and intense toxic cyanobacterial blooms. As input of nutrients is high during the year, the aim of the present study was to evaluate the role of other variables related to changes in cyanobacterial biomass and composition. The dominant group found over the entire study period was Cyanobacteria $197 \%$ of total biomass), which contributed to low diversity. A shift of nitrogen-fixing (Anabaena circinalis and Cylindrospermopsis raciborskii) and non nitrogen-fixing (Microcystis aeruginosa) cyanobacteria was observed. Redundancy analysis indicated that physical factors such as temperature, changes in the mixing zone and light intensity were the main driving factors of the seasonal succession. Nitrogenfixing cyanobacteria dominated in periods of low light in the deepest mixing zone, and also seemed to have experienced stronger grazing effects as the density of the large zooplankton group was related to cyanobacteria biomass. $M$. aeruginosa bloomed in warm stratified waters, high water levels and during months with more daylight, when the zooplankton density was drastically reduced. Although the long-standing dominance of cyanobacteria may be related to high nutrient availability, the present study showed that under high and constant input of nutrients, other factors, especially physical variables, present a more plausible explanation to promote changes in species composition.
\end{abstract}

KEY WORDS: Cyanobacterial bloom · Cylindrospermopsis · Microcystis $\cdot$ Anabaena $\cdot$ Zooplankton Resale or republication not permitted without written consent of the publisher

\section{INTRODUCTION}

Although cyanobacteria occur in oligo- and mesotrophic waters, they are frequently associated with enriched systems, where many species are able to pro- duce high biomass and form blooms. These blooms are a direct consequence of eutrophication, and are presumed to be primarily associated with waters that are toward the upper reaches of the trophic spectrum (Watson et al. 1997). While such blooms are not new, 
reports of surface scum have become much more numerous since the mid-20th century. Harmful algal blooms caused by cyanobacteria (CyanoHABs) are one of the most severe problems in freshwater ecosystems nowadays. These often-toxic blooms and the dense surface scums are indicative of water quality deterioration and food-web changes, and can be responsible for the mortality of fish, domestic animals and even humans (Paerl \& Huisman 2009).

Cyanobacteria blooms occur in waters during calm stratified conditions with high temperatures and adequate nutrient supplies (Huszar et al. 2000). Cyanobacterial dominance is mostly related to favourable bottom-up factors (Briand et al. 2002, Marinho \& Huszar 2002), since they are widely known for their ability to minimize grazing pressure, through different effects on zooplankton community: mechanical interference (difficulty in manipulating and ingesting large colonies or filaments), assimilation (low amounts of essential nutrients) and toxicity (De Bernardi \& Giussani 1990). However, some zooplankton species have developed physiological resistance to cyanotoxins (Fulton \& Paerl 1988) or behavioural adaptations to avoid toxic cells (Reinikainen et al. 1998). Our present insights are still far from forming a comprehensive theory explaining the causes, occurrence and control of cyanobacterial blooms. In general, high-density blooms of cyanobacteria will become more likely if the founder population is capable of suppressing its main predators and concomitantly its main competitors, the faster-growing phytoplankton species.

The occurrence of CyanoHABs has also increased worldwide and many toxic blooms have been recorded in Brazil (Bouvy et al. 2000, Molica et al. 2005). For example, intense eutrophication in Funil Reservoir in southeastern Brazil has transformed a system with low primary production, low phosphorus content and dominance of green algae into a eutrophic reservoir with high phosphorus concentrations and dominance of cyanobacteria, including toxic blooms of Microcystis aeruginosa (Ferrão-Filho et al. 2009). Soares et al. (2008) demonstrated that in the last decade, mean total phosphorus (TP) concentration increased 3 to 6 times, mean dissolved inorganic nitrogen (DIN) increased 10 to 25 times, and maximum chlorophyll a (chl a) increased from 14 to $168.9 \mu \mathrm{g} \mathrm{l}^{-1}$ in Funil Reservoir.

The aim of the present study was to evaluate the factors controlling changes in biomass and species composition in a reservoir annually dominated by cyanobacteria. The hypothesis is that in a system receiving a high input of nutrients, other variables are the major factors driving the changes in cyanobacterial species dominance.

\section{MATERIALS AND METHODS}

Study site. Funil Reservoir is a hydropower reservoir $\left(22^{\circ} 30^{\prime} \mathrm{S}, 44^{\circ} 45^{\prime} \mathrm{W}\right.$, altitude $440 \mathrm{~m}$, Cwa climate (i.e. warm temperature, dry winter, hot summer in the Köppen climate classification system) with $16800 \mathrm{~km}^{2}$ of catchment area, a surface area of $40 \mathrm{~km}^{2}$, mean and maximum depths of 22 and $70 \mathrm{~m}$, respectively, a total volume of $890 \times 10^{6} \mathrm{~m}^{3}$ and a retention time of 25 to 80 d. Funil Reservoir was constructed at the end of the 1960s by damming the Paraíba do Sul River. This river has a strong influence on the water quality of the reservoir because its basin drains and receives effluents from the most densely populated area in Brazil. Consequently, eutrophication has dramatically accelerated in recent decades, leading to intense cyanobacterial blooms (Soares et al. 2008). The occurrence of cyanobacteria is especially important because the water from the reservoir is diverted to the Guandu River, which is the main source of water supply for 9 million people in the Rio de Janeiro metropolitan region.

Field sampling. Water samples were taken monthly from June 2002 to June 2003 at a station near the dam (Fig. 1) with a Van Dorn bottle at the surface and at depths corresponding to $1 \%$ of the euphotic zone, $15 \mathrm{~m}$, and $30 \mathrm{~m}$ (total depth at the station: $50 \mathrm{~m}$ ). Water temperature, $\mathrm{pH}$, conductivity, and dissolved oxygen (DO) were measured in situ with a multi-sensor probe (YSI model 6920) at the same depths where water samples were taken. Water transparency was estimated by the Secchi disk extinction depth. Samples for phytoplankton analysis were placed in dark bottles and fixed with Lugol's solution. Samples for zooplankton were concentrated in a plankton net (68 $\mu \mathrm{m}$ mesh) and preserved in $4 \%$ buffered formaldehyde.

Sample and data analysis. Samples were collected for analysis of total nutrients (TP and total nitrogen [TN]) and dissolved nutrients (soluble reactive phosphorus [SRP], ammonium-nitrogen $\left[\mathrm{NH}_{4}{ }^{+}-\mathrm{N}\right]$, nitratenitrogen $\left[\mathrm{NO}_{3}{ }^{-}-\mathrm{N}\right]$ and nitrite-nitrogen $\left.\left[\mathrm{NO}_{2}^{-}-\mathrm{N}\right]\right)$. Samples for dissolved nutrients were filtered through GF/C filters (Whatman). Laboratory analysis for nutrients was performed according to standard spectrophotometric techniques. SRP was determined by the ascorbic acid method, $\mathrm{NO}_{3}{ }^{-}-\mathrm{N}$ and $\mathrm{NO}_{2}{ }^{-}-\mathrm{N}$ by cadmium reduction followed by colorimetric determination of $\mathrm{NO}_{2}{ }^{-}-\mathrm{N}$ and $\mathrm{NH}_{4}{ }^{+}-\mathrm{N}$ by the phenolhypochlorite method (Wetzel \& Likens 1990). DIN was calculated as the sum of $\mathrm{NH}_{4}{ }^{+}-\mathrm{N}, \mathrm{NO}_{3}{ }^{-} \mathrm{N}$ and $\mathrm{NO}_{2}{ }^{-}-\mathrm{N}$. The euphotic zone $\left(z_{\text {eu }}\right)$ was estimated as 2.7 times the Secchi disk extinction depth (Cole 1994). The mixing zone $\left(z_{\text {mix }}\right)$ was identified through the temperature profiles, considering density gradients $>0.02 \mathrm{~kg} \mathrm{~m}^{-3}$ (Reynolds 1992). 


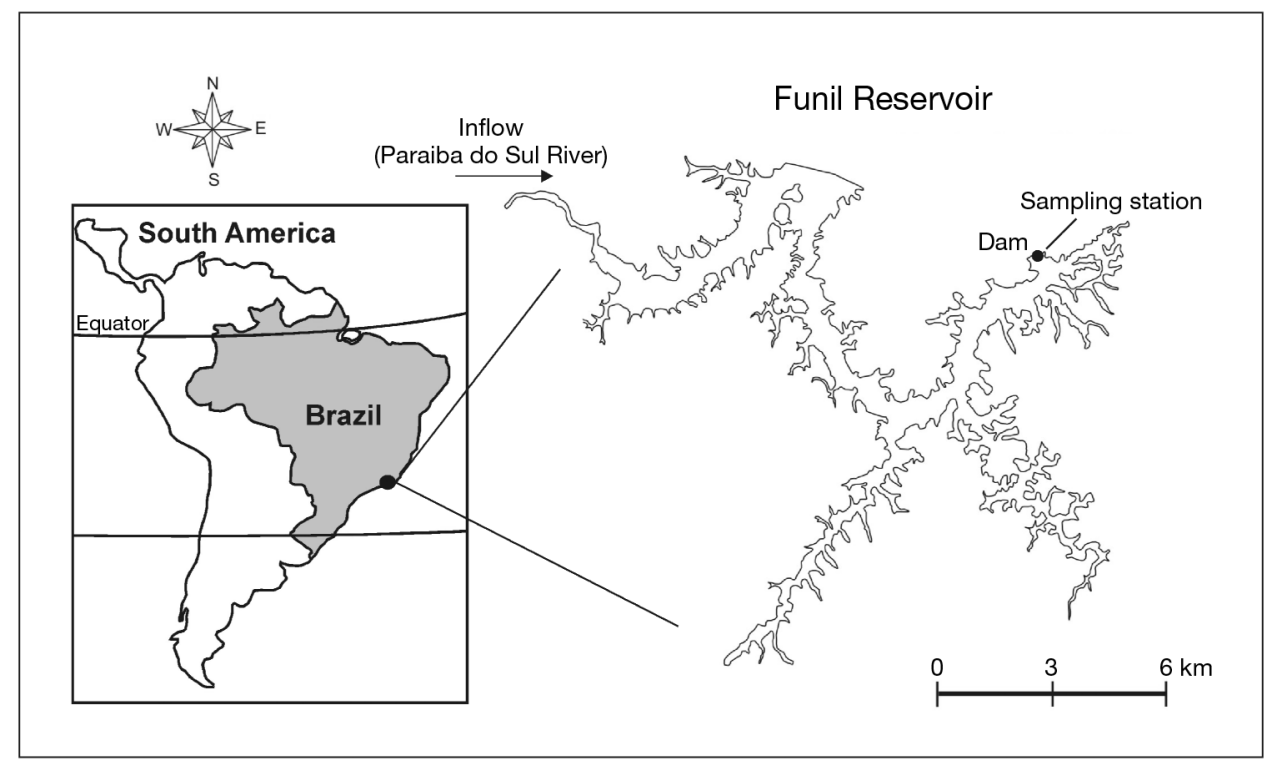

Fig. 1. Funil Reservoir in southeastern Brazil showing the geographical location and sampling station

Phytoplankton samples were fixed with Lugol's solution and populations were enumerated in random fields (Uhelinger 1964), using the settling technique (Utermöhl 1958). The units (cells, colonies and filaments) were enumerated at least to 100 specimens of the most frequent species ( $\mathrm{p}<0.05$, Lund et al. 1958). Specific biomass $\left(\mathrm{mg} \mathrm{l}^{-1}\right)$ was estimated from the product of the population and mean unit volume of each species (Edler 1979), assuming a specific density of phytoplankton cells of $1 \mathrm{~g} \mathrm{~cm}^{-3}$. In general, average cell size was based on measurements of at least 30 cells. Species diversity $\left(H^{\prime}\right)$ was estimated by the Shannon-Wiener index (Shannon \& Weaver 1963), based on the biomass and expressed in bits per milligram. Zooplankton density (individuals [ind.] $\mathrm{l}^{-1}$ ) was estimated in Sedgwick-Rafter counting chambers.

The study year was divided into periods according to the mixing pattern and chl a concentration (Soares et al. 2008). Four periods were identified for Funil Reservoir, including June to October 2002 (Period I), November to December 2002 (Period II), January to March 2003 (Period III) and April to June 2003 (Period IV). All variables were tested for differences between periods using Kruskal-Wallis tests. If there was a significant difference between periods for any variable ( $p<0.05)$, then these variables were tested further to determine if any variables were similar among the 4 periods using post-hoc Mann-Whitney tests to reduce the number of variables for redundancy analysis (RDA). These statistical analyses were carried out with the program StatView 5.01. RDA was performed using canonical ordination software (CANOCO v. 4.5) to ordinate phytoplankton data from different periods with environmental and biological variables. Data was $\log _{10}(x+1)$ transformed. The forward selection of RDA was used to determine the minimum number of explanatory factors that could explain statistically significant $(p<0.05)$ proportions of variation in the species data. The selected variables were water temperature (WT), precipitation (Prec), $z_{\text {eu }}, z_{\text {mix }}$, SRP, DIN, microphage filter feeders of bacteria and phytoplankton up to $20 \mu \mathrm{m}$ (MF20), microphage filter feeders of bacteria and phytoplankton up to $60 \mu \mathrm{m}$ (MF60) and other zooplankton groups (Oth). Although highly significant, $\mathrm{pH}$ was excluded from RDA analysis because it seemed that it was more related to the increase in cyanobacterial biomass than it was a controlling variable. The significance of these variables was assessed using Monte Carlo permutation tests (with 999 unrestricted permutations).

\section{RESULTS}

\section{Chemical and physical regime}

The average retention time in Funil Reservoir during the study year was $41.5 \mathrm{~d}$. Retention time was around 30 d during Periods I and II (June to January), and increased to values of around $80 \mathrm{~d}$ in April (Period IV). The net water flow through the reservoir was higher in the wet warm period, corresponding to the end of Periods II and III (October to January). Net water flow varied from $247 \mathrm{~m}^{-2} \mathrm{~s}^{-1}$ in January to $-250 \mathrm{~m}^{-2} \mathrm{~s}^{-1}$ in April. Although the spillways for hydroelectric generation in Funil Reservoir are located near the bottom, an 
unusual surface outflow occurred at the end of Period II (Fig. 2). The water column was stratified during Periods II and III, and was isothermal at the end of Period I and during Period IV (Fig. 3). Water temperature at the surface increased from $22.3^{\circ} \mathrm{C}$ in Period I to $27.3^{\circ} \mathrm{C}$ in Period II $\left(H_{3,52}=30.2, \mathrm{p}<0.001\right)$ (Table 1$)$. The mixing zone increased from $4.5 \mathrm{~m}$ in Period III to $12.0 \mathrm{~m}$ in Period IV $\left(H_{3,52}=26.8, \mathrm{p}<0.001\right)$, reaching $30 \mathrm{~m}$ only on certain dates in Periods I and IV (Fig. 3). The system was turbid, with the lowest light availability in Period II $\left(z_{\mathrm{eu}}=1.6 \mathrm{~m}\right)$ and the highest in Period IV $\left(z_{\mathrm{eu}}=9.0 \mathrm{~m}\right)$ $\left(H_{3,52}=38.3, \mathrm{p}<0.001\right)$, corresponding to the variation in phytoplankton biomass. The DO concentration profile indicated a chemical stratification in Funil Reservoir only in Period I. Although there was a slight decrease in the oxygen concentration from the surface to the bottom, anoxic conditions were not observed. The $\mathrm{pH}$ was alkaline at the surface, especially in Peri- ods I and III, with the entire water column being slightly acidic at the end of Period III and beginning of Period IV, reaching higher values in Period II (8.7) $\left(H_{3,52}=11.9, \mathrm{p}<0.05\right)$ (Table 1$)$. The reservoir is eutrophic exhibiting high to slightly high nutrient concentrations throughout the year. SRP concentrations were high throughout the year, decreasing only in Period III (median $=0.6 \mu \mathrm{M})$. The DIN concentration was ca. $20 \mu \mathrm{M}$ in all periods, exhibiting a strong stratification pattern, with higher concentrations at the surface and decreasing vertically. The DIN represented $81 \%$ of the $\mathrm{TN}$, and $\mathrm{NO}_{3}{ }^{-}-\mathrm{N}$ was the most important form of dissolved nitrogen in Funil Reservoir (91\% of the total DIN). No significant difference in nutrient concentrations was observed between the periods, or in relation to the TN/TP ratio, which varied from 15 to 24 in Periods I and II, respectively. For more details of limnological variables, see Soares et al. (2008).

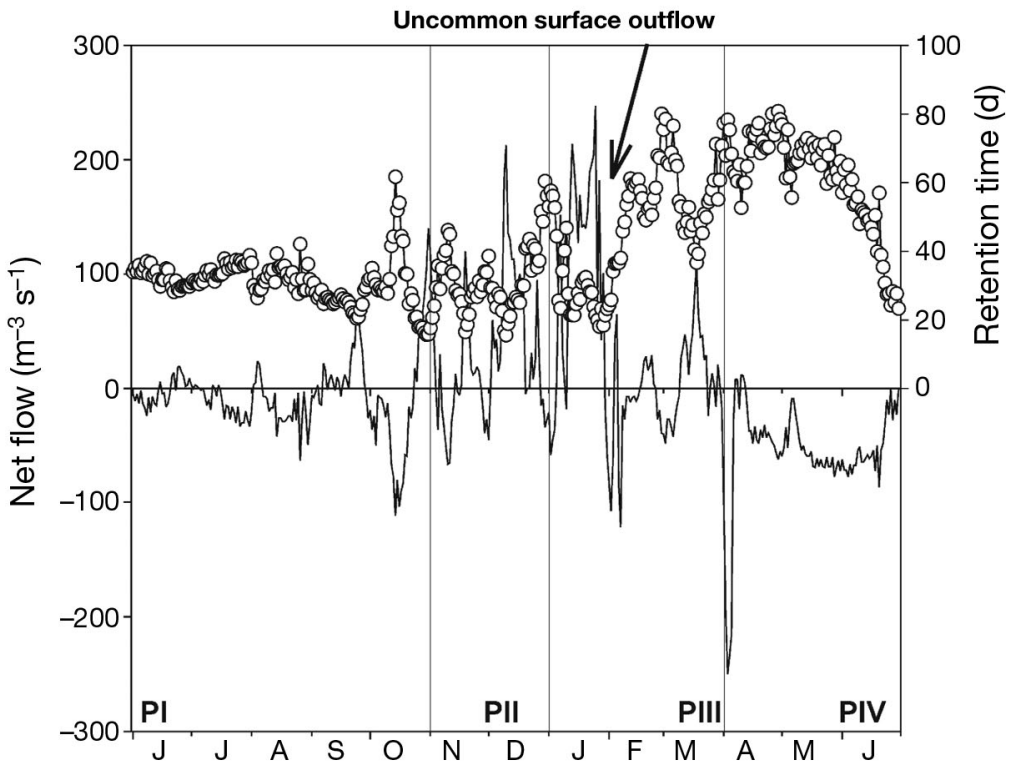

Fig. 2. Net flow (-) and retention time (O) in Funil Reservoir during the study period indicating the occurrence of an uncommon surface outflow. P: Period

\section{Phytoplankton composition and biomass}

A total of 96 phytoplankton taxa were identified during the year. Chlorophyceae (green algae) contributed the most taxa (34), followed by Cyanobacteria (21), Bacillariophyceae (13), Cryptophyceae (9), Zygnematophyceae (8), Euglenophyceae (5), Chrysophyceae (3), and Dinophyceae (3). Phytoplankton biomass consisted mainly of cyanobacteria (Fig. 4). Only 3 of the 96 species were dominant throughout the year: the nitrogen-fixing cyanobacteria, Anabaena circinalis Rabenhorst ex Bornet et Flahault and Cylindrospermopsis raciborskii (Woloszyńska) Seenayya et Subba Raju, and the colonial cyanobacterium Microcystis aeruginosa (Kützing) Kützing. Together, these 3 species comprised $92 \%$ of the total annual biomass. In general, nitrogen-fixing cyanobacteria occurred throughout the year; whereas non nitrogen-fixing cyanobacteria,

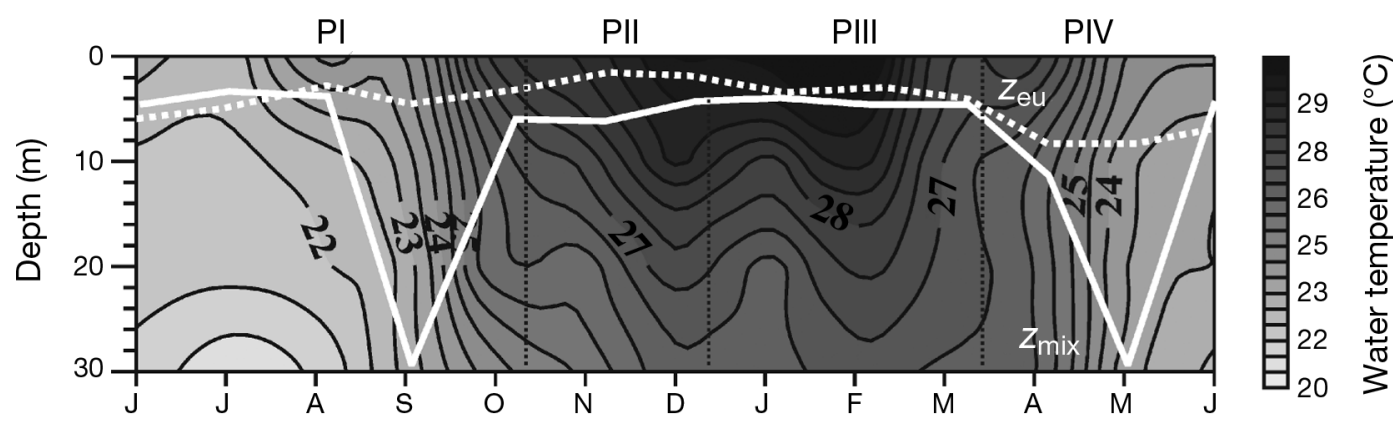

Fig. 3. Water temperature $\left({ }^{\circ} \mathrm{C}\right)$ in Funil Reservoir by depth and by month from June 2002 to June 2003. $z_{\text {eu }}$ : euphotic zone; $Z_{\text {mix }}$ : mixing zone; P: Period 
Table 1. Medians and ranges of environmental and biotic variables during the 4 periods in Funil Reservoir. $z_{\text {eu }}$ : euphotic zone; $z_{\text {mix }}$ : mixing zone; TP: total phosphorus; SRP: soluble reactive phosphorus; TN: total nitrogen; DIN; dissolved inorganic nitrogen

\begin{tabular}{|c|c|c|c|c|}
\hline & Period I & Period II & Period III & Period IV \\
\hline Water temperature $\left({ }^{\circ} \mathrm{C}\right)$ & $22.3(20.6-28.0)$ & $27.3(25.1-30.0)$ & $27.0(26.2-31.2)$ & $23.8(22.4-28.1)$ \\
\hline$z_{\text {mix }}(\mathrm{m})$ & $5.5(4.5-30)$ & $6.0(4.5-7.5)$ & $4.5(3.5-4.5)$ & $12.0(7.0-30)$ \\
\hline$z_{\mathrm{eu}}(\mathrm{m})$ & $4.8(3.3-6.0)$ & $1.6(1.5-1.8)$ & $4.5(3.9-4.8)$ & $9.0(8.1-9.0)$ \\
\hline Dissolved oxygen (\% saturation) & $90.2(44.3-147.2)$ & $81.1(57.7-85.3)$ & $90.2(10.2-157.3)$ & $81.0(58.1-121.3)$ \\
\hline $\mathrm{pH}$ & $7.6(6.3-9.3)$ & $8.7(6.7-9.9)$ & $6.5(6.0-9.4)$ & $6.9(6.3-7.0)$ \\
\hline Conductivity $\left(\mu \mathrm{S} \mathrm{cm}^{-1}\right)$ & $75.2(69.3-81.6)$ & $82.6(76.4-99.3)$ & $86.6(73.1-106.7)$ & $90.5(87.1-106.9)$ \\
\hline $\mathrm{TP}(\mu \mathrm{mol})$ & $3.3(0.5-22.0)$ & $3.0(1.0-3.7)$ & $2.1(1.1-4.3)$ & - \\
\hline $\mathrm{SRP}(\mu \mathrm{mol})$ & $1.6(0.3-3.1)$ & $1.8(1.1-2.5)$ & $0.4(0.3-1.6)$ & $1.4(0.4-3.6)$ \\
\hline $\mathrm{TN}(\mu \mathrm{mol})$ & $21.4(14.5-51.1)$ & $25.5(20.3-40.6)$ & $21.5(11.7-32.7)$ & $23.6(15.7-38.4)$ \\
\hline DIN $(\mu \mathrm{mol})$ & $17.8(10.1-39.6)$ & $20.9(11.9-27.7)$ & $18.3(10.0-30.1)$ & $20.7(12.6-30.8)$ \\
\hline TN/TP ratio & $15(2-42)$ & $24(16-75)$ & $23(7-60)$ & - \\
\hline Chl a $\left(\mu g l^{-1}\right)$ & $8.5(1.4-21.9)$ & $26.9(0.8-78.3)$ & $1.6(0.2-6.3)$ & $0.5(0.1-2.1)$ \\
\hline Phytoplankton biomass $\left(\mathrm{mg} \mathrm{l}^{-1}\right)$ & $3.8(0.1-16.0)$ & $15.4(0.5-138.1)$ & $2.0(0-19.3)$ & $0.1(0-1.0)$ \\
\hline Phytoplankton diversity (bits $\mathrm{mg}^{-1}$ ) & $1.6(0.8-3.0)$ & $1.5(0.2-2.2)$ & $1.0(0.5-1.4)$ & $1.2(0.4-3.3)$ \\
\hline Zooplankton density (ind. $\mathrm{l}^{-1}$ ) & $61(9-232)$ & $23(6-210)$ & $42(9-232)$ & $22(6-133)$ \\
\hline
\end{tabular}

especially $M$. aeruginosa, were responsible for the highest biomass during Period II (Fig. 5A,B). The dominance of $A$. circinalis and C. raciborskii varied during Period I in all depths (Fig. 5C,D); however, the highest biomass was observed in Period II $\left(H_{3,52}=6.6, \mathrm{p}<0.05\right)$ when $M$. aeruginosa reached $138.1 \mathrm{mg} \mathrm{l}^{-1}$ at the surface in December (Fig. 5E). During the bloom, M. aeruginosa was responsible for more than $95 \%$ of total biomass at the surface and was the main species found at all depths. A. circinalis and C. raciborskii were also present throughout the water column. The large increase in biomass caused decreases in light availability and increases in $\mathrm{pH}$ (Table 1). Although $M$. aeruginosa appeared mostly as single cells or in small groups of cells during most of the year, colonies made up 67 to $90 \%$ of the population bloom in November and December. Due to high precipitation in Period II, an unusual surface outflow was responsible for the abrupt decrease in the surface biomass in this period (Figs. 4 \& 5). Phytoplankton biomass started to increase again at the beginning of Period III, with the dominance of C. raciborskii, when the maximum biomass was $19.3 \mathrm{mg} \mathrm{l}^{-1}$ at $4 \mathrm{~m}$ in February. Neither C. raciborskii nor other species were able to reach high biomass in this period, and the cyanobacteria dominance decreased from Periods III to IV $\left(H_{3,52}=22.1\right.$, $\mathrm{p}<0.001$ ), reaching values of about $1 \mathrm{mg} \mathrm{l}^{-1}$ in Period IV

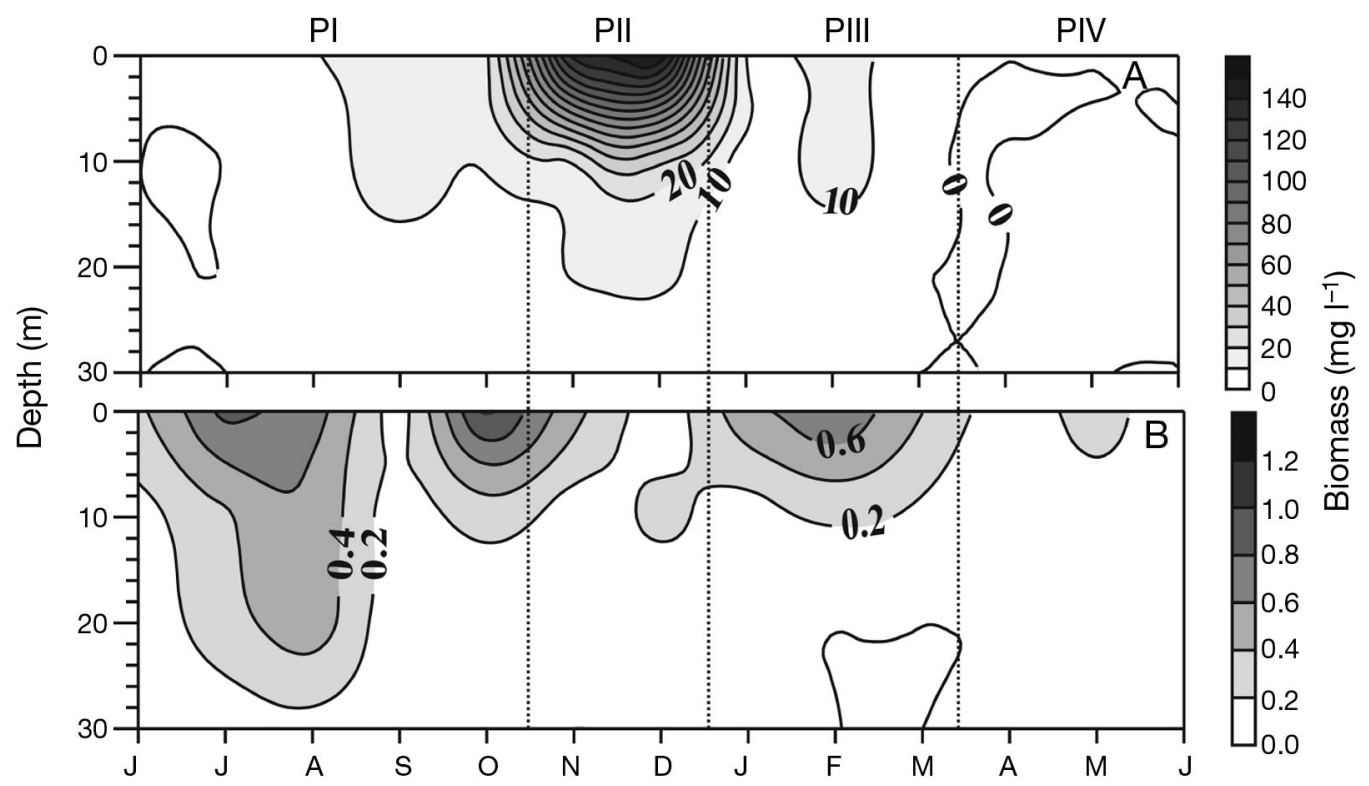

Fig. 4. Phytoplankton biomass (mg fresh weight $\mathrm{l}^{-1}$ ) for (A) cyanobacteria and (B) other algae in Funil Reservoir by depth and by month from June 2002 to June 2003. P: Period 
(Figs. 4 \& 5). Consequently, water transparency increased, and the highest values were observed during this period (Table 1). Due to the decreases of cyanobacteria in Period IV, other groups, especially cryptomonads and green algae, increased their contribution to total biomass, although cyanobacteria was still the dominant group, even at low biomass. The annual dominance of cyanobacteria in Funil Reservoir caused low diversity, as indicated by $H^{\prime}$, during the entire study year, especially in Periods III and IV (Table 1).

\section{Zooplankton}

The zooplankton community comprised 40 taxa: rotifers (25), cladocerans (8), copepods (4) and others (3). The median of zooplankton total density decreased from 61 ind. $\mathrm{l}^{-1}$ in Period $\mathrm{I}$ to 23 ind. $\mathrm{l}^{-1}$ in Periods II and IV, but no significant differences were observed among the periods. A very low density of the entire community occurred during the bloom of Microcystis aeruginosa in December (Fig. 6A). The

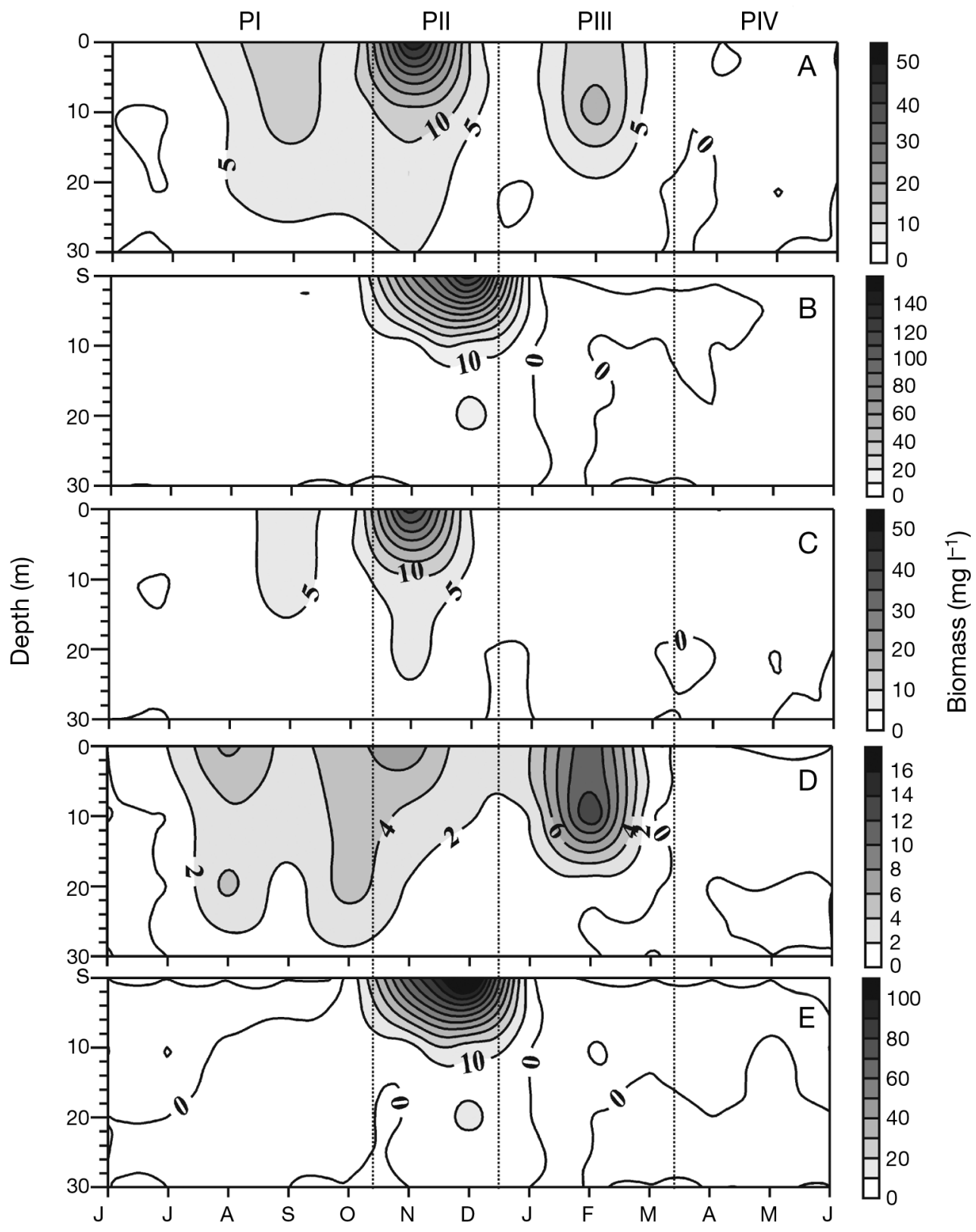

Fig. 5. Cyanobacterial biomass $\left(\mathrm{mg} \mathrm{l}^{-1}\right.$ ) for (A) nitrogen-fixing cyanobacteria, (B) non-nitrogen-fixing cyanobacteria, (C) Anabaena circinalis, (D) Cylindrospermopsis raciborskii and (E) Microcystis aeruginosa in Funil Reservoir by depth and by month from June 2002 to June 2003. P: Period 
most important groups were copepods (55\% of total annual density) and rotifers (37\%). The zooplankton community of Funil Reservoir was classified into functional groups according to feeding preferences. Microphage filter feeders of detritus, bacteria and phytoplankton up to $20 \mu \mathrm{m}$ were responsible for $68 \%$ of total density, microphage filter feeders of bacteria and phytoplankton up to $60 \mu \mathrm{m}$ for $12 \%$, and other zooplankton groups for $20 \%$ (Fig. 6). The highest values of all groups were observed at the surface, especially in Period I, and in a particular month corresponding to the end of the stratified Period III. While the MF20 group was the most important during all periods, the MF60 group had an increased contribution in Period I, especially in the upper $10 \mathrm{~m}$ of the water column $\left(H_{3,52}=8.4, \mathrm{p}<0.05\right)$ (Fig. 6B-D).

\section{Relationships between phytoplankton and explanatory variables}

The RDA using forward selection and the screened environmental data yielded 6 significant variables, $z_{\mathrm{eu}}$ $(F=16.63, \mathrm{p}=0.002), z_{\mathrm{mix}}(F=6.55, \mathrm{p}=0.006), \mathrm{DIN}$ $(F=4.75, \mathrm{p}=0.006)$, water temperature $(F=3.71$, $\mathrm{p}=0.008)$, precipitation $(F=3.34, \mathrm{p}=0.04)$ and MF60 $(F=3.30, \mathrm{p}=0.04)$. Together, these 6 variables accounted for $93 \%$ of the total variance in phytoplankton data. The first RDA axis accounted for $85 \%$ (Table 2) of the relationship between species and environmental variables, and was mainly positively correlated with water temperature and MF60 and negatively with $z_{\text {eu }}$. Axis 2 (10.8\% of total variance) was mainly positively correlated with $z_{\text {mix }}$ and negatively with precipitation and water temperature

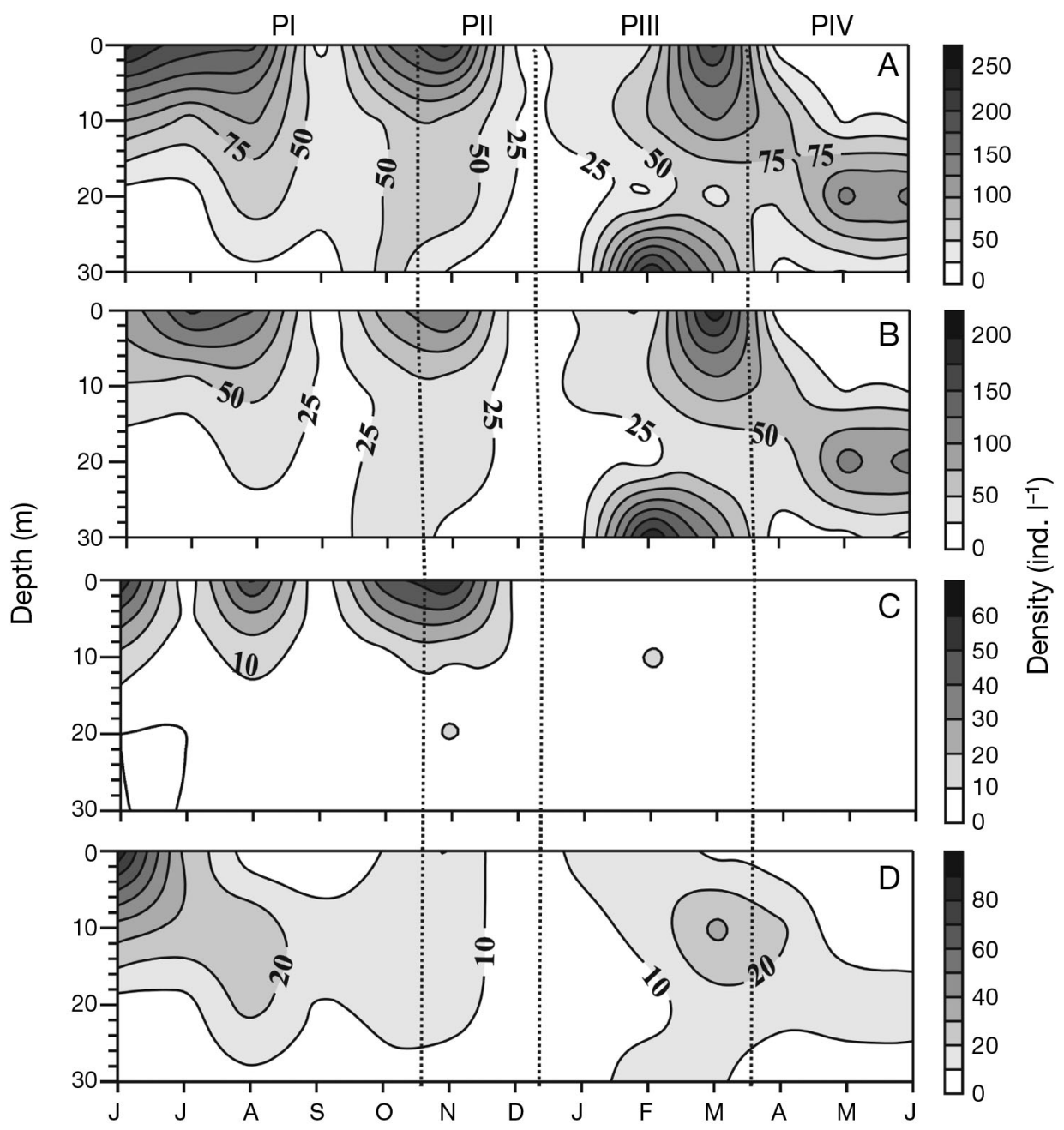

Fig. 6. Zooplankton density (ind. $\mathrm{l}^{-1}$ ) for (A) total zooplankton, (B) microphage filter feeders of detritus, bacteria and phytoplankton up to $20 \mu \mathrm{m}$, (C) microphage filter feeders of bacteria and phytoplankton up to $60 \mu \mathrm{m}$ and (D) other zooplankton groups in Funil Reservoir by depth and by month from June 2002 to June 2003. P: Period 
(Table 3, Fig. 7). Samples were distributed in the RDA triplot according to the main characteristics of the 4 periods. The first axis clearly separates, on the right (Fig. 7), samples from warm, turbid and stratified periods, mainly characterized by high biomass of cyanobacteria and zooplankton. These include samples from the end of Period I, Period II, and the beginning of Period III. On the left are mainly samples from the beginning of Period I and Period IV, which are characterized by a deep mixing zone, increase in water transparency, and contribution of other phytoplankton groups.

\section{DISCUSSION}

\section{Cyanobacterial occurrence and seasonal succession}

The increase in nutrient supply, especially P and N, has been proposed as a predictor of the dominance of CyanoHABs (Downing et al. 2001). Intense eutrophication in Funil Reservoir is directly related to the persistence of cyanobacterial dominance. During the entire study period, SRP and DIN concentrations were always above the values considered limiting to phytoplankton

Table 2. Summary statistics for the first 2 axes of redundancy analysis (RDA) performed in Funil Reservoir

\begin{tabular}{|lcc|}
\hline Results & Axis 1 & Axis 2 \\
\hline Eigenvalues $(\lambda)$ & 0.467 & 0.062 \\
Species-environment correlations & 0.893 & 0.467 \\
Cumulative percentage variance & 84.7 & 95.9 \\
$\quad$ of species-environment relationship (\%) & & \\
\hline
\end{tabular}

Table 3. Correlation coefficients between environmental and biotic vectors with ordination axes 1 and 2 for redundancy analysis (RDA) performed for Funil Reservoir. $z_{\text {eu }}$ : euphotic zone; $z_{\text {mix }}$ : mixing zone; SRP: soluble reactive phosphorus; DIN: dissolved inorganic nitrogen; MF20: microphage filter feeders of detritus, bacteria and phytoplankton up to $20 \mu \mathrm{m}$; MF60: microphage filter feeders of bacteria and phytoplankton up to $60 \mu \mathrm{m}$

\begin{tabular}{|c|c|c|}
\hline \multirow[t]{2}{*}{ Variables } & \multicolumn{2}{|c|}{ Canonical correlation coefficient } \\
\hline & Axis 1 & Axis 2 \\
\hline Water temperature & 0.391 & -0.296 \\
\hline Precipitation & 0.147 & -0.302 \\
\hline$z_{\mathrm{eu}}$ & -0.647 & 0.113 \\
\hline$Z_{\text {mix }}$ & 0.038 & 0.193 \\
\hline SRP & -0.027 & -0.098 \\
\hline DIN & 0.258 & 0.039 \\
\hline MF20 & 0.039 & 0.181 \\
\hline MF60 & 0.350 & 0.137 \\
\hline Other zooplankton & 0.029 & 0.183 \\
\hline
\end{tabular}

growth (Reynolds 1997) and the extremely reduced occurrence of filamentous cyanobacteria carrying heterocytes indicated plenty of $\mathrm{N}$ in this system (Anabaena circinalis: $0.1 \%$; Cylindrospermopsis raciborskii: $0.4 \%$ ).

Moreover, significant differences in SRP and DIN concentrations were not observed during the year (Soares et al. 2008) indicating a low influence by the nutrient dynamics in temporal variability. Although low TN/TP ratios have been considered to be beneficial for both nitrogen- and non-nitrogen-fixing cyanobacteria (Bulgakov \& Levich 1999), some studies have suggested that nutrient concentrations (total $\mathrm{P}$ and total N) are better predictors of average cyanobacteria dominance than is the N/P ratio (Trimbee \& Prepas 1987). Moreover, experimental studies have shown that a low N/P ratio could be a consequence of

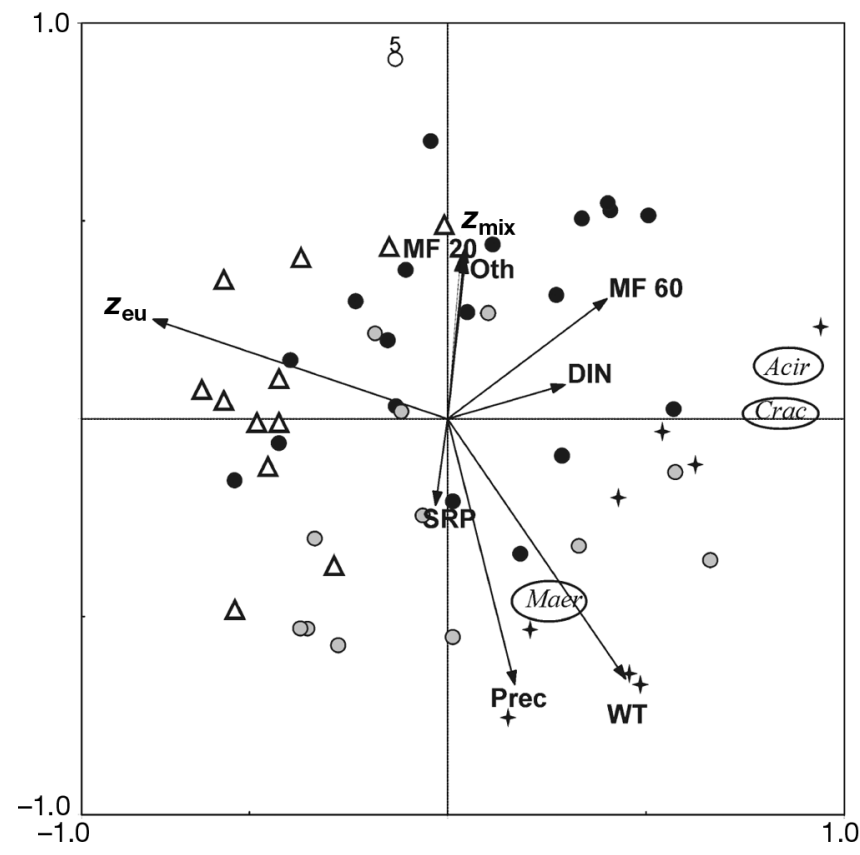

Fig. 7. RDA ordination diagram considering samples of 4 recognized periods from June 2002 to June 2003 in Funil Reservoir, with abiotic variables and zooplankton density as vectors, and the most numerous cyanobacterial taxa (Anabaena circinalis, Cylindrospermopsis raciborskii and Microcystis aeruginosa) on bi-dimensional space of the first and second axes. Black dots represent samples from Period I (mixed and intermediate biomass), stars represent samples from Period II (stratified and high biomass), gray dots represent samples from Period III (stratified and low biomass) and triangles represent samples from the Period IV (mixed and low biomass). WT: water temperature; Pre: precipitation; $z_{\mathrm{eu}}$ : euphotic zone; $z_{\text {mix }}$ : mixing zone; SRP: soluble reactive phosphorus; DIN: dissolved inorganic nitrogen; MF20:microphage filter feeders of detritus, bacteria and phytoplankton up to 20 Hm; MF60: microphage filter feeders of bacteria and phytoplankton up to $60 \mu \mathrm{m}$; Oth: other zooplankton groups; Acir: Anabaena circinalis; Crac: Cylindrospermopsis raciborskii; Maer: Microcystis aeruginosa 
the capacities and rates of cyanobacterial uptake of $\mathrm{N}$ and P (Marinho \& Azevedo 2007). In Funil Reservoir, TN/TP ratios did not vary significantly during the year, and were not correlated with cyanobacterial biomass. TN/TP ratios were similar in Periods II and III (24 and 23, respectively), even with significant differences in biomass during these periods (15.4 and $2.0 \mathrm{mg} \mathrm{l}^{-1}$, respectively). Smith et al. (1995) showed that an N/P mass ratio of 22:1 defines a distinct boundary between lakes dominated by nitrogen-fixing cyanobacteria and lakes in which these algae are relatively rare. We also did not observe this relationship in Funil Reservoir because the median TN/TP changed from 15 in Period I to 24 in Period II, but nitrogen-fixing cyanobacteria was present in high biomass during both conditions, despite the dominance of Microcystis aeruginosa in Period II.

Once the system does not present nutrient limitation during the entire year, other factors affect the seasonal substitution of species. During this study, the main significant changes during the year were temperature and consequently changes in mixing depth. As the trophic state changes towards hypereutrophic conditions, physical variables become more important in promoting the development of different phytoplankton species that are adapted to the different conditions (Naselli-Flores 2000). The significant effect of temperature on the annual variability of phytoplankton is observed in the distribution of samples along the RDA triplot. The increase in temperature in Periods II and III promoted a decrease in the mixing zone, and consequently higher biomass. In contrast, reduced biomass was observed in periods of the lowest temperatures and in the mixed water column. Cyanobacterial dominance has been related to high temperatures even in the tropics (Bouvy et al. 2000, Huszar et al. 2000, Marinho \& Huszar 2002), and the biomass of the 3 main species from Funil Reservoir was also positively related with temperature. Moreover, the management of the reservoir, directly related to precipitation levels, is also an important physical factor, because it was responsible for disrupting the stability during the Microcystis aeruginosa bloom. The synergy of environmental factors allied with certain adaptations of the main species more plausibly explains the replacement of species and especially the bloom of $M$. aeruginosa in Period II.

Anabaena, Cylindrospermopsis and Microcystis are common cyanobacterial genera in tropical waters (Huszar \& Silva 1999, Hoeger et al. 2004). However, as far as we know, their co-dominance has only been recorded in Brazilian reservoirs (Marinho \& Huszar 2002, Molica et al. 2005). The 3 genera have similar characteristics, such as large unit size, buoyancy regulation (Padisák 1997, Brookes et al. 1999, Brookes \& Ganf 2001) and potential toxicity (Molica et al. 2002,
2005, Wu et al. 2006). While large size and toxicity can prevent consumption of some cyanobacteria by most zooplankton, buoyancy regulation provides a means of rapid adjustment of vertical position through thermally stable layers. With respect to the toxins production, high concentrations of microcystins were found in Funil Reservoir during the $M$. aeruginosa bloom, and high saxitoxin levels were observed in February 2003 when $C$. raciborskii reached its maximum biomass and was the dominant species in Funil Reservoir (FerrãoFilho et al. 2009).

Microcystis was the most important genus in the reservoir in terms of reaching a high biomass. Its success has frequently been associated with long-lasting vertical stratification of the water column, as is observed during summer and autumn in tropical reservoirs (Marinho \& Huszar 2002) or at the end of summer in temperate systems (Reynolds 2006). The reduction in the mixing zone was an important key factor in promoting $M$. aeruginosa blooms in Funil Reservoir. Although Cylindrospermopsis raciborskii has been associated with non-turbulent environments (Padisák 1997) and reduced rates of vertical mixing (Saker \& Griffiths 2001), the dominance of C. raciborskii in Funil Reservoir occurred during mixing periods, which is in accordance with observations in some other tropical reservoirs (Bouvy et al. 2000, Marinho \& Huszar 2002). No chemical changes were observed between Periods I and II, and most of the changes (decrease in nutrients, increase in $\mathrm{pH}$ and decrease in light linked to the algae self-shading) were a consequence of the bloom. Low $\mathrm{CO}_{2}$ and high $\mathrm{pH}$ are able to promote or allow cyanobacterial dominance (Shapiro 1990, Caraco \& Miller 1998) and many studies have reported a direct relationship between high $\mathrm{pH}$ and cyanobacterial biomass (Briand et al. 2002). However, the significance of $\mathrm{pH}$ as a cause or consequence of cyanobacterial blooms is still not well defined. Higher values of $\mathrm{pH}$ in Funil Reservoir were observed in Period II, corresponding to the months with high biomass and precipitation. Once precipitation continued to be high in Period III, we did not assume changes in $\mathrm{pH}$ were related to external input, and $\mathrm{pH}$ values decreased directly with cyanobacterial biomass. Consequently, in Funil Reservoir, the increase in $\mathrm{pH}$ seemed to be more related to the increase in photosynthetic activity during the $M$. aeruginosa bloom.

Temperature seems to be the most important factor affecting the appearance and development of Cylindrospermopsis raciborskii and, although it was initially described as exclusively tropical, there are an increasing number of observations of this species in temperate systems (Briand et al. 2004). Briand et al. (2004) pointed out that the increase in water temperature in temperate lakes is the key factor in the expanding range of C. raci- 
borskii and included it as a tropical species with high light tolerance. Controlled experiments have indicated that the optimum temperature for C. raciborskii growth and development varies from $25^{\circ} \mathrm{C}$ to $32^{\circ} \mathrm{C}$ (Padisák 1997, Saker et al. 1999, Briand et al. 2004, M. C. S. Soares et al. unpubl.), and Microcystis aeruginosa is considered temperature tolerant (Dokulil \& Teubner 2000) with the optimum growth registered between $23^{\circ} \mathrm{C}$ (Reynolds 2006) and $32^{\circ} \mathrm{C}$ (M. C. S. Soares et al. unpubl.). Anabaena circinalis is known to dominate at temperatures below $25^{\circ} \mathrm{C}$ and the collapse of this species in an Australian reservoir coincided with a sudden increase in the average daily temperature at a depth of $1 \mathrm{~m}$ from 24.5 to $26.6^{\circ} \mathrm{C}$ (Bormans et al. 2005). Nalewajko \& Murphy (2001) found that Anabaena sp. grew optimally at 28 to $32^{\circ} \mathrm{C}$. However, C. raciborskii and $M$. aeruginosa showed reduced growth at temperatures below $20^{\circ} \mathrm{C}$ (M. C. S. Soares et al. unpubl.), and Li \& Watanabe (2001) found that 45 of 50 strains of Anabaena had high optimal growth above $20^{\circ} \mathrm{C}$. In Funil Reservoir, the monthly average temperature during the coldest months is around $13^{\circ} \mathrm{C}$, when daily temperatures easily reach values close to $11^{\circ} \mathrm{C}$. It seems that that the reduced cyanobacterial biomass during this period was especially related to the low tolerance range of these organisms to these low temperatures (M. C. S. Soares et al. unpubl.).

The annual variation in light availability also seems to be an important factor favouring Microcystis aeruginosa dominance over other species during summer. Cylindrospermopsis raciborskii is particularly known to tolerate low light (Padisák 1997), and experiments have shown that the optimum growth of this species occurs at light intensities below 300 umol quanta $\mathrm{m}^{-2} \mathrm{~s}^{-1}$ (Saker et al. 1999). Moreover, this species can survive and grow under various irradiance conditions (Briand et al. 2004) and its dominance in many systems has been attributed to its physiological adaptation to growth in low light environments (Padisák 1997, Bouvy et al. 2000). During the period of dominance of C. raciborskii in Funil Reservoir, light availability was around $400 \mu \mathrm{mol}$ quanta $\mathrm{m}^{-2} \mathrm{~s}^{-1}$. M. aeruginosa has been reported as being adapted to high light intensities (Robarts \& Zohary 1987). However, during the $M$. aeruginosa bloom, the irradiance at the surface reached $2000 \mu \mathrm{mol}$ quanta $\mathrm{m}^{-2} \mathrm{~s}^{-1}$ (F. Roland unpubl. data), which favoured this species. In the same period, C. raciborskii was only found below $4 \mathrm{~m}$, where light availability was around $500 \mu \mathrm{mol}$ quanta $\mathrm{m}^{-2} \mathrm{~s}^{-1}$.

The dominance of Cylindrospermopsis raciborskii has caused a reduction in diversity in reservoirs in northeastern Brazil (Bouvy et al. 2000) and in New Zealand lakes (Ryan \& Hamilton 2003). However, in the present study, the highest diversity was observed during Period I when Anabaena circinalis and C. raci- borskii were the main species. Moreover, the decrease in cyanobacterial biomass in Period IV did not lead to an increase in diversity. Similar to our data, a decrease in diversity related to C. raciborskii dominance was not observed in an African lake (Berger et al. 2006).

\section{Zooplankton and shifts in cyanobacteria dominance}

Compared with phytoplankton, zooplankton occurred in low abundance, with little variation during the year. The main organisms were MF20, in accordance to the usual predominance of small grazers in systems dominated by cyanobacteria (Bouvy et al. 2001). The increase in biomass of Cylindrospermopsis raciborskii in Period I was followed by an increase in the density of MF60 organisms, especially Daphnia gessneri and copepods. Laboratory experiments have indicated that D. magna was able to grow and reproduce when fed with mixed diets of C. raciborskii from Funil Reservoir and green algae (Soares et al. 2009). However, the same study showed that high proportions of this cyanobacterium in a mixed feed significantly lowered food intake, which led to lower growth rates, indicating that energy limitation and nutritional inadequacy are most probably the major controlling factors. In another tropical reservoir, zooplankton biomass (mainly rotifers and copepods) also increased in parallel with C. raciborskii abundance during the bloom, and decreased drastically after it (Bouvy et al. 2001). Copepods from the same environment were able to cut long filaments of this cyanobacterium, and the small particles were available to other organisms (Bouvy et al. 2001). As a consequence, $C$. raciborskii can be under grazing pressure when other algae are absent. In contrast, a decrease in the entire zooplankton community was observed during the Microcystis aeruginosa bloom. The rotifer Brachionus calyciflorus was able to feed on $C$. raciborskii and $M$. aeruginosa and effectively removed phytoplankton cells, although all the animals died on a sole diet of $M$. aeruginosa (M. C. S. Soares et al. unpubl.). However, in the same study, M. aeruginosa was offered as food only in single cell form, and almost $100 \%$ of the biomass at the surface during the bloom was formed by colonies. Laboratory experiments showed that the copepod Notodiaptomus iheringi did not affect the growth of large cyanobacterial colonies and filaments in the natural community, but significantly reduced the growth of small $(<30 \mu \mathrm{m})$ colonies (Panosso et al. 2003). The inability of the dominant zooplankton community (MF20) to eat large particles, as well as the possible toxicity of $M$. aeruginosa can also be considered strategies used to avoid and decrease the grazing pressure. Despite the fact that nitrogen-fixing cyanobacteria seemed to experience higher grazing 


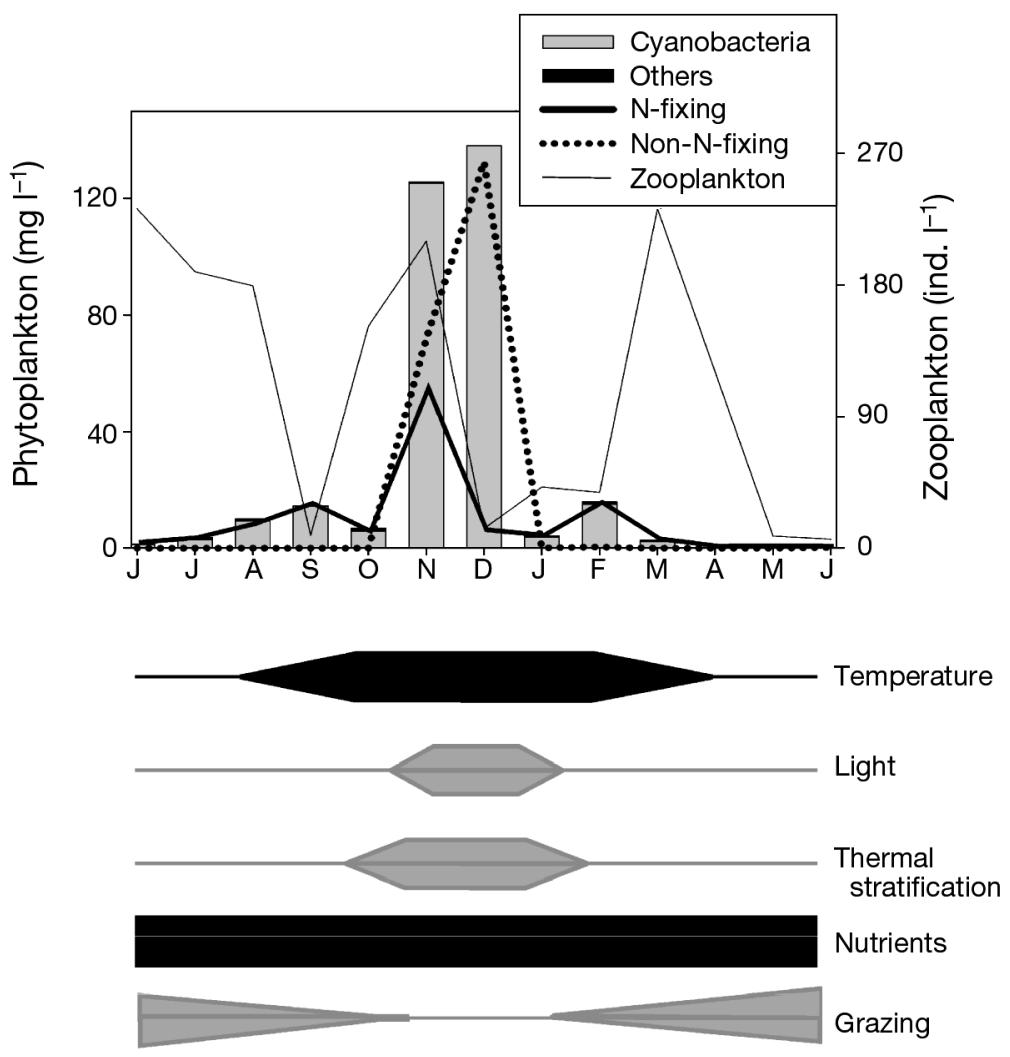

Fig. 8. Schematic representation of the variability of the main factors related to the occurrence and seasonal variability of cyanobacteria, other groups, nitrogen-fixing and non-nitrogen-fixing cyanobacteria and total zooplankton in Funil Reservoir. Black horizontal bars indicate factors that positively affected growth of both groups and grey horizontal bars indicate factors that positively affected Microcystis aeruginosa bloom

pressure than $M$. aeruginosa, the total zooplankton density was still reduced related to the food availability. Despite the possible effect of toxins and even the low nutritional value of the available food (Von Elert et al. 2005) it also appears that the cyanobacteria biomass is extremely high so that the potential top-down effect may never be felt. Elser \& Goldman (1991) showed that algal control by grazing was reduced in systems with higher trophic levels. Some studies in tropical regions have also found a weak relationship between phytoplankton and zooplankton in more eutrophic conditions (Von Rückert \& Giani 2008), even for species other than cyanobacteria.

\section{CONCLUSIONS}

The intense eutrophication has promoted annual cyanobacterial dominance in Funil Reservoir. When there are high concentrations of nutrients, other factors such as temperature, changes in mixing zone, light and grazing pressure are decisive to the temporal substitution of species. The effect of the main variables in the occurrence and substitution of the major species in Funil Reservoir is summarized in Fig. 8. Low temperature during winter months seems to have caused the decrease in total cyanobacterial biomass; however, changes in column stability led to different periods of dominance of nitrogen-fixing and nonnitrogen-fixing cyanobacteria. Thermal stability and high light intensity in summer months were also important factors related to the substitution of species along the year, favouring Microcystis aeruginosa. Nutrient availability was constant during the entire year, favouring all species. Despite the lack of correlation between zooplankton and total biomass, nitrogenfixing cyanobacteria seem to have experienced a stronger grazing effect because the entire zooplankton community was reduced during the $M$. aeruginosa bloom. The present study showed that under high and constant input of nutrients, other factors, especially physical variables, more plausibly explain changes in species composition in a system annually dominated by cyanobacteria.

Acknowledgements. The authors are grateful to A. Cimbleris (Furnas Centrais Elétricas S.A.) and F. Roland (Universidade Federal de Juiz de Fora) for data about Funil Reservoir. Two anonymous referees provided helpful comments on an earlier version of this manuscript. M.C.S.S. is grateful to CAPES (Foundation for the Coordination of Higher Education and Graduate Training). This research was supported by FAPERJ (Foundation for Research Support of the State of Rio de Janeiro), FUNASA (National Health Foundation), and CNPq (Brazilian National Research Council).

\section{LITERATURE CITED}

Berger C, Ba N, Gugger M, Bouvy M and others (2006) Seasonal dynamics and toxicity of Cylindrospermopsis raciborskii in lake Guiers (Senegal, West Africa). FEMS Microbiol Ecol 57:355-366

Bormans M, Ford PW, Fabbro L (2005) Spatial and temporal variability in cyanobacterial populations controlled by physical processes. J Plankton Res 27:61-70

Bouvy M, Falcão D, Marinho M, Pagano M, Moura A (2000) Occurrence of Cylindrospermopsis (Cyanobacteria) in 39 Brazilian tropical reservoirs during the 1998 drought. Aquat Microb Ecol 23:13-27

> Bouvy M, Pagano M, Trousselier M (2001) Effects of a cyanobacterial bloom (Cylindrospermopsis raciborskii) on bacteria and zooplankton communities in Ingazeira reservoir (northeast Brazil). Aquat Microb Ecol 25:215-227 
Briand JF, Robillot C, Quiblier-Lloberas C, Humbert JF, Couté A, Bernard C (2002) Environmental context of Cylindrospermopsis raciborskii (Cyanobacteria) blooms in a shallow pond in France. Water Res 36:3183-3192

Briand JF, Leboulanger C, Humbert JF, Bernard C, Dufour P (2004) Cylindrospermopsis raciborskii (Cyanobacteria) invasion at mid-latitudes: Selection, wide physiological tolerance or global warming? J Phycol 40:231-238

Brookes JD, Ganf GG (2001) Variations in the buoyancy response of Microcystis aeruginosa to nitrogen, phosphorus and light. J Plankton Res 23:1399-1411

Brookes J, Ganf G, Green D, Whittington J (1999) The influence of light and nutrients on buoyancy, filament aggregation and flotation of Anabaena circinalis. J Plankton Res 21:327-341

Bulgakov NG, Levich AP (1999) The nitrogen:phosphorus ratio as a factor regulation phytoplankton community structure. Arch Hydrobiol 146:3-22

> Caraco NF, Miller R (1998) Effects of $\mathrm{CO}_{2}$ on competition between a cyanobacterium and eukaryotic phytoplankton. Can J Fish Aquat Sci 55:54-62

Cole GA (1994) Textbook of limnology, 4th edn. Waveland Press, Prospect Heights, IL

> De Bernardi R, Giussani G (1990) Are blue-green algae a suitable food for zooplankton? An overview. Hydrobiologia 200-201:29-41

Dokulil MT, Teubner K (2000) Cyanobacterial dominance in lakes. Hydrobiologia 438:1-12

Downing JA, Watson SB, McCauley E (2001) Predicting cyanobacteria dominance in lakes. Can J Fish Aquat Sci 58:1905-1908

Edler L (1979) Recommendations for marine biological studies in the Baltic Sea. Phytoplankton and chlorophyll. Working Group 11, Baltic Marine Biologists, National Swedish Environmental Protection Board, Stockholm

Elser JJ, Goldman CR (1991) Zooplankton effects on phytoplankton in lakes of contrasting trophic status. Limnol Oceanogr 36:64-90

> Ferrão-Filho AS, Soares MCS, Magalhães VF, Azevedo SMFO (2009) Biomonitoring of cyanotoxins in two tropical reservoirs through cladoceran toxicity bioassays. Ecotoxicol Environ Safe 72:479-489

Fulton RS, Paerl HW (1988) Effects of the blue-green alga Microcystis aeruginosa on zooplankton competitive relations. Oecologia 76:383-389

> Hoeger SJ, Shaw G, Hitzfeld BC, Dietrich DR (2004) Occurrence and elimination of cyanobacterial toxins in two Australian drinking water treatment plants. Toxicon 43: 639-649

Huszar VLM, Silva LHS (1999) Cinco décadas de estudos sobre a ecologia do fitoplâncton no Brasil. Limnotemas 2: 1-22

> Huszar VLM, Silva LHS, Marinho MM, Domingos P, Sant'Anna C (2000) Cyanoprokaryote assemblages in eight productive tropical Brazilian waters. Hydrobiologia 424: $67-77$

Li R, Watanabe MM (2001) Physiological properties of planktic species of Anabaena (Cyanobacteria) and their taxonomic value at species level. Arch Hydrobiol (Suppl Algol Stud) 103:31-45

Lund JWH, Kipling C, Lecren ED (1958) The inverted microscope method of estimating algal number and statistical basis of estimating by counting. Hydrobiologia 11: $143-170$

> Marinho MM, Azevedo SMFO (2007) Influence of N/P ratio on competitive abilities for nitrogen and phosphorus by Microcystis aeruginosa and Aulacoseira distans. Aquat Ecol 41:525-533
Marinho MM, Huszar VLM (2002) Nutrient availability and physical conditions as controlling factors of phytoplankton composition and biomass in a tropical reservoir (Southeastern Brazil). Arch Hydrobiol 153:443-468

Molica R, Onodera H, García C, Rivas M and others (2002) Toxins in the freshwater cyanobacterium Cylindrospermopsis raciborskii (Cyanophyceae) isolated from Tabocas reservoir in Caruaru, Brazil, including demonstration of a newsaxitoxin analogue. Phycologia 41:606-611

Molica RJR, Oliveira EJA, Carvalho PVVC, Costa ANSF, Cunha MCC, Melo GL, Azevedo SMFO (2005) Occurrence of saxitoxins and an anatoxin-a(s)-like anticholinesterase in a Brazilian drinking water supply. Harmful Algae 4:743-753

> Nalewajko C, Murphy TP (2001) Effects of temperature, and availability of nitrogen and phosphorus on the abundance of Anabaena and Microcystis in Lake Biwa, Japan: an experimental approach. Limnology 2:45-48

Naselli-Flores L (2000) Phytoplankton assemblages in twenty-one Sicilian reservoirs: relationships between species composition and environmental factors. Hydrobiologia 424:1-11

Padisák J (1997) Cylindrospermopsis raciborskii (Woloszynska) Seenaya et Subba Raju, an expanding, highly adaptive cyanobacterium: worldwide distribution and review of its ecology. Arch Hydrobiol 107:563-593

Paerl HW, Huisman J (2009) Climate change: a catalyst for global expansion of harmful cyanobacterial blooms. Environ Microbiol Rep 1:27-37

> Panosso R, Carlsson P, Kozlowsky-Suzuki B, Azevedo SMFO, Granéli E (2003) Effect of grazing by a neotropical copepod, Notodiaptomus, on a natural cyanobacterial assemblage and on toxic and non-toxic cyanobacterial strains. J Plankton Res 25:1169-1175

Reinikainen M, Hietala J, Walls M (1998) Adaptations and resistance of zooplankton to stress: effects of genetic environmental and physiological factors. Ecotoxicol Environ Safe 40:77-80

Reynolds CS (1992) Dynamics, selection and composition of phytoplankton in relation to vertical structure in lakes. Arch Hydrobiol 35:13-31

Reynolds CS (1997) Vegetation processes in the pelagic: a model for ecosystem theory. In: Kinne O (ed) Excellence in ecology, Book 9. Ecology Institute, Oldendorf/Luhe

Reynolds CS (2006) The ecology of phytoplankton (ecology, biodiversity and conservation). Cambridge University Press, Cambridge

Robarts RD, Zohary T (1987) Temperature effects on photosynthetic capacity, respiration, and growth rates of bloom-forming cyanobacteria. NZ J Mar Freshw Res 21: 391-399

Ryan EF, Hamilton DP (2003) Recent occurrence of Cylindrospermopsis raciborskii in Waikato lakes of New Zealand. NZ J Mar Freshw Res 37:829-836

> Saker ML, Griffiths DJ (2001) Occurrence of blooms of the cyanobacterium Cylindrospermopsis raciborskii (Woloszynska) Seenayya and Subba Raju in a north Queensland domestic water supply. Mar Freshw Res 52:907-915

Saker ML, Neilan B, Griffiths DJ (1999) Two morphological forms of Cylindrospermopsis raciborskii (Cyanobacteria) isolated from Solomon Dam, Palm Island, Queensland. J Phycol 35:599-606

Shannon CE, Weaver W (1963) The mathematical theory of communication. Illinois University Press, Urbana, IL

Shapiro J (1990) Current beliefs regarding dominance by bluegreens: the case for the importance of $\mathrm{CO}_{2}$ and $\mathrm{pH}$. Verh Int Ver Theor Angew Limnol 24:38-54 
Smith VH, Bierman VJ, Jones BL, Havens KE (1995) Historical trends in the Lake Okeechobee ecosystem IV. Nitrogen:phosphorus ratios, cyanobacterial dominance, and nitrogen fixation potential. Arch Hydrobiol (Suppl Algol Stud) 107:71-88

Soares MCS, Marinho MM, Huszar VLM, Branco CWC, Azevedo SMFO (2008) The effects of water retention time and watershed features on the limnology of two tropical reservoirs in Brazil. Lakes Reservoirs: Res Manag 13: $257-269$

Soares MCS, Lürling M, Panosso R, Huszar VLM (2009) Effects of the cyanobacterium Cylindrospermopsis raciborskii on feeding and life-history characteristics of the grazer Daphnia magna. Ecotoxicol Environ Safe 72: 1183-1189

Trimbee AM, Prepas EE (1987) Evaluation of total phosphorus as a predictor of the relative biomass of blue-green algae with emphasis on Alberta lakes. Can J Fish Aquat Sci 44:1337-1342

Uhelinger V (1964) Ètude statistique des méthodes de dénobrement planctonique. Arch Sci 17:121-123

Editorial responsibility: Patricia Glibert, Cambridge, Maryland, USA
Utermöhl H (1958) Zur Vervolkommung der quantitativen Phytoplankton-methodik. Mitt Int Ver Theor Angew Limnol 9:1-38

Von Elert E, Oberer L, Merkel P, Huhn T, Blom JF (2005) Cyanopeptolin 954, a chlorine-containing chymotrypsin inhibitor of Microcystis aeruginosa NIVA Cya 43. J Nat Prod 68:1324-1327

Von Rückert G, Giani A (2008) Biological interactions in the plankton community of a tropical eutrophic reservoir: Is the phytoplankton controlled by zooplankton? J Plankton Res 30:1157-1168

Watson SB, McCauley E, Downing JA (1997) Patterns in phytoplankton taxonomic composition across temperate lakes of differing nutrient status. Limnol Oceanogr 42: 487-495

Wetzel RG, Likens GE (1990) Limnological analyses. Springer-Verlag, New York

Wu SK, Xie P, Liang GD, Wang SB, Liang XM (2006) Relationships between microcystins and environmental parameters in 30 subtropical shallow lakes along the Yangtze River, China. Freshw Biol 51:2309-2319

Submitted: November 4, 2008; Accepted: June 12, 2009 Proofs received from author(s): September 14, 2009 